\title{
Retraction Note: Antimalarial efficacy of Pongamia pinnata (L) Pierre against Plasmodium falciparum (3D7 strain) and Plasmodium berghei (ANKA)
}

\section{P. V. V. Satish and K. Sunita*}

\section{Retraction to: BMC Complement Altern Med 17, 458 (2017) https://doi.org/10.1186/s12906-017-1958-y}

The Editor in Chief has retracted this article [1] because concerns have been raised regarding two figures presented here. Specifically:

- In Fig. 2 it appears that 'Control Positive' and 'Leaf' show the same image and that 'Bark' and 'Root' show the same image

- In Fig. 5 it appears that ' $\mathrm{CH}$ Leaves' and ' $\mathrm{CH}$ Bark' show the same image, albeit rotated

- In Fig. 5 it appears that 'CH Flowers' and 'EA Bark' show the same image, albeit rotated

- In Fig. 5 it appears that 'HE Bark' and 'EA Roots' show the same image, albeit rotated

- In Fig. 5 it appears that 'EA Flowers' and 'HE Roots' shows the same image

The authors provided additional data, but were not able to show original images for these figures. The Editor-in-Chief therefore no longer has confidence in the integrity of the data in this article.

Both authors, P.V.V. Satish and K. Sunita have not explicitly stated whether they agree to this retraction notice.
Published online: 10 May 2021

\section{Reference}

1. Satish $P$, Sunita K. Antimalarial efficacy of Pongamia pinnata $(L)$ Pierre against Plasmodium falciparum (3D7 strain) and Plasmodium berghei (ANKA). BMC Complement Altern Med. 2017;17(1):458. https://doi.org/10.1186/s12 906-017-1958-y.
The original article can be found online at https://doi.org/10.1186/s12906017-1958-y.

* Correspondence: sunitakanikaram@gmail.com

Department of Zoology and Aquaculture, Acharya Nagarjuna University, Nagarjuna Nagar, Guntur district, Andhra Pradesh 522510, India

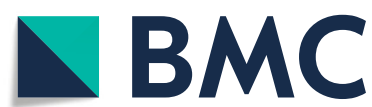

(0) The Author(s). 2021 Open Access This article is licensed under a Creative Commons Attribution 4.0 International License, which permits use, sharing, adaptation, distribution and reproduction in any medium or format, as long as you give appropriate credit to the original author(s) and the source, provide a link to the Creative Commons licence, and indicate if changes were made. The images or other third party material in this article are included in the article's Creative Commons licence, unless indicated otherwise in a credit line to the material. If material is not included in the article's Creative Commons licence and your intended use is not permitted by statutory regulation or exceeds the permitted use, you will need to obtain permission directly from the copyright holder. To view a copy of this licence, visit http://creativecommons.org/licenses/by/4.0/ The Creative Commons Public Domain Dedication waiver (http://creativecommons.org/publicdomain/zero/1.0/) applies to the data made available in this article, unless otherwise stated in a credit line to the data. 